\title{
PENDIDIKAN KECAKAPAN HIDUP DI PESANTREN DARUL HIKAM BANJARAN BANDUNG
}

\author{
LIFE SKILLS EDUCATION \\ AT PESANTREN DARUL HIKAM BANJARAN BANDUNG
}

\author{
Juju Saepudin \\ Balai Penelitian dan Pengembangan Agama Jakarta \\ Jl. Rawa Kuning No. 6 Pulo Gebang Cakung - Jakarta Timur \\ Email : saep.17.khasep@gmail.com
}

Naskah diterima 4 Februari 2016, direvisi 20 Maret 2016, disetujui 30 Maret 2016

\begin{abstract}
Abstrak
Pesantren as one of the institutions of Islamic education in Indonesia is considered to have contributed quite significantly in the development of national education. However, the issue encountered by people from various social stratifications in education, including pesantren, is the low quality and relevance of education to the labor market needs. In fact, many pesantren alumni have no choice of employment to meet their needs in the real life. This paper presents the results of research on independence-based education life skills and local potential in Pesantren Darul Hikam Banjaran Bandung regency. The study was conducted using qualitative approach and case study designed naturalistically. Data was collected through observation, interview and documentation methods. Inductive data analysis identified models of life skills education for students with self-reliance and local potential capitals. Two-wheeled vehicle mechanical skill in Pesantren Darul Hikam that uses local curriculum with a ratio of $20 \%$ theory and $80 \%$ practice empowers senior students to be the teachers assisted by local BLK has been able to equip the students with skills in automotive detailing allowing them to be ready to enter the professional world.
\end{abstract}

Keywords: Education, Life Skills, Pesantren

\section{Abstrak}

Pesantren sebagai salah satu lembaga pendidikan Islam di Indonesia dinilai memiliki kontribusi yang tidak kecil dalam pembangunan pendidikan nasional. Namun persoalan masyarakat dari berbagai stratifikasi sosial dalam dunia pendidikan termasuk pesantren adalah rendahnya mutu dan relevansi pendidikan dengan kebutuhan pasar kerja. Bahkan, banyak alumni pesantren yang tidak memiliki pilihan lapangan kerja untuk menenuhi kebutuhan hidupnya di masyarakat. Tulisan ini menyajikan hasil penelitian tentang pendidikan kecakapan hidup berbasis kemandirian dan potensi lokal di Pesantren Darul Hikam Banjaran Kabupaten Bandung. Penelitian dilakukan dengan menggunakan pendekatan kualitatif dan rancangan studi kasus yang bersifat naturalistik. Tehnik pengumpulan melalui pengamatan, wawancara mendalam dan metode dokumentasi. Analisa data secara induktif menemukan model pendidikan kecakapan hidup bagi santri dengan modal kemandirian dan potensi lokal. Pendidikan kecakapan hidup otomotif roda dua di Pesantren Darul Hikam menggunakan kurikulum lokal dengan perbandingan $20 \%$ teori dan $80 \%$ praktek, memberdayakan santri senior sebagai guru dan dibantu dari BLK setempat telah mampu membekali keterampilan santri dibidang otomotif sehingga siap memasuki dunia kerja.

Kata Kunci: Pendidikan, Kecakapan Hidup, Pesantren 


\section{PENDAHULUAN}

Secara substansial, pesantren merupakan institusi keagamaan yang tidak mungkin dilepaskan dari masyarakat. Pesantren tumbuh dan berkembang dari dan untuk masyarakat dengan memposisikan dirinya sebagai bagian masyarakat dalam pengertian yang transformatif. Dalam konteks ini, pendidikan pesantren pada dasarnya merupakan pendidikan yang sarat dengan nuansa transformasi sosial. Pesantren berikhtiar meletakkan visi dan kiprahnya dalam kerangka pengabdian sosial yang pada mulanya ditekankan kepada pembentukan moral keagamaan dan kemudian dikembangkan kepada rintisan-rintisan pengembangan yang lebih sistematis dan terpadu. ${ }^{1}$

Pada awal berdirinya, pengabdian pesantren terhadap masyarakat sesuai zamannya, berbentuk sangat sederhana dan bisa dibilang sangat alami. Pengabdian tersebut diwujudkan dengan pelayanan keagamaan kepada masyarakat, menyediakan wadah bagi sosialisasi anakanak, dan sebagai tempat bagi para remaja yang datang dari berbagai daerah yang sangat jauh untuk menjalani semacam "ritus peralihan" dari fase remaja ke fase selanjutnya. ${ }^{2}$ Dalam bentuk seperti itu pesantren terlibat aktif dalam pengkajian keagamaan dan pola-pola sejenis seperti lembaga pendidikan yang dikembangkan masyarakat luas. Tahap perkembangan berikutnya, pesantren menjadi bagian dari sistem pendidikan nasional yang dinilai

${ }^{1}$ Abd A'la. 2006. Pembaruan Pesantren. Cetakan I. Yogyakarta: Pustaka Pesantren, h. 2.

${ }^{2}$ Taufik Abdullah. 1987. Islam dan Masyarakat: Pantulan Sejarah Indonesia. Cetakan I. Jakarta: LP3ES, h. 111. memiliki kontribusi yang tidak kecil dalam pembangunan Sumber Daya Manusia (SDM) Indonesia.

Namun demikian, persoalan masyarakat dari berbagai stratifikasi sosial dalam dunia pendidikan termasuk pesantren adalah rendahnya mutu dan relevansi pendidikan dengan kebutuhan pasar kerja. Padahal, pada era globalisasi dengan persaingan yang terlalu ketat dewasa ini, membangun SDM tidaklah cukup dengan membentuk budi pekerti saja, melainkan diperlukan pula berbagai pengetahuan dan ketrampilan (skill) yang selama ini masih kurang mampu dipenuhi oleh pondok pesantren, karena berbagai faktor seperti masih tertutupnya pola fikir kyai untuk menerima perkembangan dan kurangnya sarana prasarana.

Berdasarkan hal di atas, tantangan pondok pesantren di zaman yang semakin mengglobal ini sangat ekstra dan luar biasa. Pesantren diharapkan memberikan layanan lebih cepat, lebih berkualitas dan lebih menguntungkan. Sementara alumni pesantren, dalam menenuhi kebutuhan hidup dimasyarakat, tidak terlalu memiliki pilihan lapangan kerja. Selain itu, Pengelolaan pendidikan pesantren secara mandiri, yang pendanaannya bersumber dari masyarakat, bahkan ada yang hanya dari pribadi kyainya.

Melihat fenomena tersebut, muncul pemikiran dan gagasan untuk mengembangkan pondok pesantren sekaligus sebagai wahana untuk menanamkan apresiasi, bahkan bibit-bibit keahlian dalam bidang sains-teknologi. Dalam kerangka ini, SDM yang dihasilkan pondok pesantren diharapkan tidak hanya 
mempunyai perspektif keilmuan yang lebih komprehensif antara bidang ilmuilmu agama dan ilmu-ilmu keduniaan tetapi juga memiliki kemampuan teoritis dan praktis tertentu yang diperlukan dalam masa industri dan pasca industri. ${ }^{3}$

Dengan demikian, menjadi suatu hal yang logis apabila pendidikan pesantren yang sudah berjalan selama ini perlu menambah orientasi layanan, yaitu pendidikan yang diorientasi kepada kecakapan hidup (life skill), sehingga dengan model tersebut mampu memberikan alternatif layanan program pendidikan yang mampu memberikan kecakapan hidup bagi santri.

Pendidikan yang beroreintasi pada kecakapan hidup sangat dibutuhkan untuk mempersiapkan peserta didik dengan bekal kecakapan hidup, baik untuk mengurus dan mengendalikan dirinya sendiri untuk berinteraksi di lingkungan sekolah dan masyarakat maupun kecakapan untuk bekerja yang dapat dijadikan sebagai sumber penghidupan. Karena pendidikan kecakapan hidup adalah pendidikan yang diorientasikan pada kecakapan hidup, agar peserta didik berani menghadapi problem kehidupan secara wajar tanpa merasa tertekan, kemudian secara kreatif menemukan serta mampu mengatasinya. Dengan melalui pembekalan kecakapan personal, kecakapan sosial, kecakapan akademik dan kecakapan vokasional yang berjalan secara sinergis serta bersifat holistik. ${ }^{4}$

${ }^{3}$ Azyumardi Azra. 2000. Pendidikan Islam, Tradisi dan Modernisasi Menuju Millenium Baru. Jakarta: Logos, hal. 48.

${ }^{4}$ Tim Broad Based Education Depdiknas. 2002. Kecakapan Hidup life Skill Melalui Pendekatan Pendidikan
Berkaca dari tuntutan dan prospek cerah seperti tersebut di atas, untuk mempertahankan kemandirian dan kelangsungan pendidikan pesantren para kyai dalam memenuhi kebutuhan pembiayaan umumnya mengadakan unit usaha yang sesuai dengan potensi yang ada, salah satunya adalah Pesantren Darul Hikam Banjaran Kabupaten Bandung yang mengembangkan pendidikan kecakapan hidup otomotif roda dua, yang dalam perkembangannya justru dijadikan model pemberdayaan ekonomi bagi para ustadz dan santri sebagai bentuk partisipasi pembiayaan hidup dan kelangsungan pendidikan pesantren.

Melalui program pemberdayaan ekonomi, pesantren ke depan dapat memacu menyelesaikan persoalan ekonomi. Sehingga pengembangan ekonomi pesantren perlu dilakukan secara bertahap, terfokus, terprogram dan dapat terukur tingkat keberhasilannya. ${ }^{5}$ Keberhasilan pengembangan ekonomi pesantren karena didukung oleh komitmen pimpinan dan komunitas pesantren yang cukup tinggi. ${ }^{6}$ Hal tersebut menunjukan pentingnya pengembangan ekonomi pesantren dengan memperhatikan potensi-potensi dan peluang-peluang yang dimiliki.

Berdasarkan uraian tersebut, peneliti tertarik untuk meneliti bagaimana penyelenggaraan pendidikan kecakapan

Berbasis Luas. Surabaya: SIC, h. 10.

${ }^{5}$ Achamad Dudin. 2013. "Pengembangan Ekonomi Pada Lima Pesantren Kabupaten Lamongan, Jawa Timur." Edukasi Jurnal Pendidikan Agama dan Keagamaan, 11 (1): 113-128.

${ }^{6}$ Wahid Khozim. 2011. Perberdayaan Ekonomi Pesantren: Studi Kasus Pesantren Nurul Mursyidah Pandeglang." Edukasi Jurnal Pendidikan Agama dan Keagamaan, 9 (1): 4252-4273. 
hidup "otomotif roda dua" di Pondok Pesantren Darul Hikam Banjaran Kabupaten Bandung. Untuk menguraikan dan memperjelas kasus permasalahan diatas, maka penelitian ini ditujukan untuk mengekplor kontek, in put, proses dan hasil yang telah dicapai dari penyelenggaraan program tersebut.

Penelitian ini ini sejalan dengan Rencana Pembangunan Jangka Panjang (RPJP) dan Renstra Pendidikan Islam Kementerian Agama 2014 - 2019 Pengembangan Pondok Pesantren difokuskan pada peningkatan mutu pendidikan dengan terwujudnya keunggulan komperatif dan kompetitif lulusan dan daya saing dalam memasuki pendidikan pada jenjang yang lebih tinggi atau memasuki dunia kerja dan dalam kebisaaan hidup islami. ${ }^{7}$

\section{Kerangka Konseptual}

\section{Hakikat Pendidikan}

Perkembangan teori dalam bidang ilmu sosial menyatakan bahwa pendidikan merupakan bagian dari modal sosial (sosial capital) dalam suatu masyarakat atau negara. Oleh karena itu, pendidikan sangat penting untuk dikembangkan sehingga dapat meningkatkan kesejahteraan masyarakat. Dari sisi teori ekonomi, pendidikan merupakan salah satu faktor produksi terpenting dalam pembangunan. ${ }^{8}$

\footnotetext{
7 RPJP dan Renstra Pendidikan Islam Kementerian Agama 2014 - 2019.

${ }^{8}$ Aziz Masyuri. 2002. Implementasi Akhlak Qur'ani. Makalah disampaikan pada Kontribusi Pesantren Terhadap Perubahan Sosial Budaya Masyarakat Indonesia. PT Telekomunikasi Indonesia Tbk. Bandung, 23 April.
}

Secara empirik, kenyataan menunjukkan bahwa negara-negara yang memiliki sumber daya manusia yang baik dan berkualitas akan lebih maju dibandingkan dengan negaranegara yang menggantungkan pada sumber daya alam yang berlimpah. Kurangnya SDM yang berkualitas merupakan akar dari semua persoalan bangsa Indonesia dewasa ini. Untuk mengatasi permasalahan tersebut, maka harus diambil langkahlangkah jangka panjang seperti membangun dan mengembangkan mental sumber daya danusia yang mandiri disertai berjiwa kompetitif melalui lembaga pendidikan seperti pondok pesantren, bagian dari sistem pendidikan nasional.

Pendidikan nasional secara normatif ditujukan untuk mencerdaskan kehidupan bangsa dan mengembangkan manusia Indonesia seutuhnya, yaitu manusia yang beriman dan bertaqwa terhadap Tuhan Yang Maha Esa, berakhlak mulia, sehat berilmu, cakap, kreatif, mandiri dan menjadi warga negara yang demokratis serta bertanggung jawab. ${ }^{9}$ Berdasarkan tujuan tersebut, maka setiap lembaga pendidikan termasuk pesantren bertugas dan berfungsi mempersiapkan peserta didik agar mampu: 1) mengembangkan kehidupan sebagai pribadi, 2) mengembangkan kehidupan untuk bermasyarakat, 3) mengembangkan kehidupan untuk berbangsa, dan 4) mempersiapkan peserta didik untuk mengikuti pendidikan yang lebih tinggi.

Konsekuensi dari hal tersebut di atas, setiap yang diajarkan harus menampilkan sosok utuh keempat kemampuan tersebut. Sehingga visi pendidikan nasional

${ }^{9}$ Undang-Undang Republik Indonesia No. 20 Tahun 2003 Tentang Sistem Pendidikan Nasional. 
di Indonesia harus mengutamakan kemandirian dan keunggulan untuk meraih kemajuan dan kemakmuran berdasarkan nilai-nilai Pancasila, yang ditempuh melalui pembelajaran dan pembudayaan bangsa dan masyarakat Indonesia. Dengan demikian, setiap insan Indonesia dituntut berpendidikan, memiliki kecapapan, berbudaya, cerdas, berakar kuat pada moral dan budaya serta berkeadilan sosial untuk menuju masyarakat Indonesia baru yaitu masyarakat madani (civil society).

\section{Kecakapan Hidup}

Kecakapan hidup merupakan padanan kata dari life skill. Secara bahasa life skill berasal dari bahasa Inggris yaitu life kalau diterjemahkan dalam bahasa Indonesia artinya hidup, sedangkan skill mempunyai arti kecakapan, kepandaian, ketrampilan. Dalam kamus ilmiah populer skill diartikan penguasaan suatu bidang. ${ }^{10}$ Secara istilah banyak pendapat dan literatur yang mengemukakan bahwa pengertian kecakapan hidup (life Skill) bukan sekedar keterampilan untuk bekerja (vokasional) tetapi memiliki makna yang lebih luas. Sebagaimana dijelaskan dalam kurikulum 2004, kecakapan hidup (life skill) adalah kecakapan yang dimiliki seseorang untuk mampu memecahkan permasalahan hidup secara wajar dan menjalani kehidupan secara bermartabat tanpa merasa tertekan, kemudian secara proaktif mencari serta menemukan solusi sehingga akhirnya mampu mengatasinya. ${ }^{11}$

${ }^{10}$ Pius Partanto dan M.Dahlan al Barry.1994. Kamus Ilmiah Populer. Surabaya: Arkola, h. 714.

${ }^{11}$ Depag. 2005. Pedoman Integrasi Life skill dalam pembelajaran.Jakarta:Direktorat Jederal Kelembagaan Agama Islam, h. 11.
Menurut konsepnya, kecakapan hidup dapat dibagi menjadi dua jenis utama, yaitu: 1). Kecakapan hidup yang bersifat umum (generic life skill) yang meliputi: kecakapan personal dan kecakapan sosial; 2). Kecakapan hidup yang bersifat khusus (specific life skill) seperti: kecakapan akademik dan kecakapan vokasional. $^{12}$ Sesuai dengan tema yang diteliti oleh penulis, maka yang dimaksud kecakapan hidup di Pesantren Darul Hikam Banjaran tergolong dalam kecakapan hidup spesifik (specific life skill) yaitu otomotif roda dua.

Kecakapan hidup spesifik adalah kecakapan untuk menghadapi pekerjaan atau keadaan tertentu. Kecakapan ini terdiri dari kecakapan akademik (academic skill) atau kecakapan intelektual, dan kecakapan vokasional (vocational skill). Kecakapan akademik terkait dengan bidang pekerjaan yang lebih memerlukan pemikiran atau kerja intelektual. Kecakapan vokasional terkait dengan bidang pekerjaan yang lebih memerlukan keterampilan motorik. Kecakapan vokasional terbagi atas kecakapan vokasional dasar (basic vocational skill) dan kecakapan vokasional khusus (occup vocational skill). ${ }^{13}$

\section{Pondok Pesantren}

Pondok pesantren adalah suatu lembaga pendidikan agama Islam yang tumbuh dan berkembang serta diakui oleh masyarakat sekitar, dengan sistem asrama (kampus) yang santri-santrinya menerima pendidikan

${ }^{12}$ Departemen Pendidikan Nasional. 2010. Model Integrasi Pendidikan Kecakapan Hidup. Jakarta: Pusat Kurikulum Badan Penelitian dan Pengembangan, h. 8.

${ }^{13}$ Ibid. h. 9. 
agama melalui sistem pengajian atau madrasah yang sepenuhnya berada di bawah kedaulatan dan kepemimpinan seorang atau beberapa orang kyai dengan ciri-ciri khas yang bersifat kharismatik serta independen dalam segala hal. ${ }^{14}$

Sejak awal pertumbuhannya, dengan bentuknya yang khas dan variatif, pondok pesantren terus berkembang. Namun perkembangan yang signifikan muncul setelah persinggungan dengan sistem persekolahan atau dikenal dengan sistem madrasi, yaitu sistem pendidikan dengan pendekatan klasikal sebagai lawan dari sistem individual yang berkembang di pondok pesantren sebelumnya.

Pesantren atau Pondok Pesantren seringkali kurang dipahami oleh masyarakat diluar lingkunganya, meski telah hadir sejak ratusan tahun silam. Padahal secara historis, pesantren merupakan lembaga pendidikan Islam yang dikembangkan secara indigenous oleh masyarakat Indonesia. Karena sebenarnya pesantren merupakan produk budaya masyarakat Indonesia yang sadar sepenuhnya akan pentingnya arti sebuah pendidikan bagi orang pribumi yang tumbuh secara natural. Terlepas dari mana tradisi dan sistem tersebut di adopsi, tidak akan mempengaruhi pola yang unik (khas) dan telah mengakar serta hidup dan berkembang di tengah-tengah masyarakat. ${ }^{15}$

Perkataan pesantren berasal dari kata santri yang mendapat awalan pe dan akhiran an yang berarti tempat tinggal

${ }^{14}$ Djamaluddin \& Abdullah Aly. 1998. Kapita Selekta Pendidikan Islam. Pustaka Setia: Bandung, h. 99.

${ }^{15}$ Ainurrafiq Dawam dan Ahmad Ta'arifin. 2005. Manajemen Madrasah Berbasis Pesantren. Yogyakarta: Listafariska Putra, h. 5. para santri. ${ }^{16}$ Karel A. Steenbrink mengutip pendapat Amir Hamzah mengatakan bahwa pendidikan pesantren dilihat dari segi bentuk dan sistemnya berasal dari India. ${ }^{17}$ Sementara HA Timur Jailani memberikan batasan pesantren adalah gabungan dari berbagai kata pondok dan pesantren. Istilah pesantren diangkat dari kata santri yang berarti murid atau santri yang berarti huruf, sebab dalam pesantren inilah mula-mula santri mengenal huruf, sedang istilah pondok berasal dari kata funduk (dalam bahasa Arab) mempunyai arti rumah penginapan atau hotel. Akan tetapi pondok di Indonesia khususnya di pulau jawa lebih mirip dengan pemondokan dalam lingkungan padepokan, yaitu perumahan sederhana yang dipetakpetak dalam bentuk kamar-kamar yang merupakan asrama bagi santri. ${ }^{18}$

Terlepas dari perbedaan pendapat mengenai asal permulaan istilah pesantren, tetapi pada hakekatnya mengandung pengertian yang sama. Perlu digaris bawahi adalah bahwa pondok pesantren sebagai salah satu lembaga pendidikan Islam di Indonesia yang mempunyai ciri-ciri khas tersendiri sampai saat ini masih tetap konsisten dalam memegang nilai-nilai, budaya serta keyakinan agama yang kuat. Bahkan, pesantren diakui sebagai lembaga pendidikan yang memiliki kemandirian dan independensi yang tinggi.

${ }^{16}$ Zamakhsyari Dhofier. Tradisi Pesantren: Studi tentang Pandangan Hidup Kyai. Jakarta: LP3ES. 1990, h. 18.

${ }^{17}$ Karel A. Steenbrink. 1974. Pesantren, Madrasah, Sekolah. Jakarta: LP3ES, h. 20.

${ }^{18} \mathrm{HA}$. Timur Jailani. 1983. Peningkatan Mutu Pendidikan Islam dan Pengembangan Perguruan Agama. Jakarta: Darmaga, h. 51 
Malik Fadjar membanggakan kemandirian pesantren dengan mengatakan bahwa kalau ditinjau dari kemandirian, pesantren lebih unggul ketimbang perguruan tinggi yang terkesan "wah" tapi malah justru menjadi lembaga pendidikan yang paling bertanggung jawab terhadap membludaknya pengangguran. ${ }^{19}$

Dalam perkembangannya, pesantren muncul dalam berbagai tipe dan pola berdasarkan bangunan fisik, kurikulum dan output yang dihasilkan. Berdasarkan bangunan fisiknya yang ideal, pesantren harus memenuhi sarana prasarana seperti: mesjid, rumah kyai, pondok, madrasah, tempat keterampilan, gedung pertemuan dan tempat olah raga. ${ }^{20}$ Pola ini menitikberatkan pelajaran keterampilan disamping pelajaran agama yang ditujukan untuk bekal kehidupan bagi santri setelah tamat dari pesantren ini.

Tipe dan pola pesantren tersebut memberikan gambaran bahwa pesantren merupakan lembaga pendidikan Islam yang berjalan dan berkembang sesuai dengan tuntutan jaman. Dimensi kegiatan sistem pendidikan dilaksanakan oleh pesantren bermuara pada sasaran utama yaitu perubahan baik secara invidual maupun kolektif. ${ }^{21}$ Perubahan tersebut berwujud pada peningkatan persepsi terhadap agama, ilmu pengetahuan dan teknologi.

${ }^{19}$ Ibid. h. 74

${ }^{20}$ Haidar Putra Daulay. 2007. Sejarah Pertumbuhan dan Pembaruan Pendidikan Islam di Indonesia. Jakarta: Kencana, h. 66-67.

${ }^{21}$ Abd Kadir M. 2015. "Pemberdayaan Santri di Pondok Pesantren Attarbiyatussakilah Kota Kendari." Al-Qalam Jurnal Penelitian Agama dan Sosial Budaya, 21 (2): 221-233.

\section{METODE PENELITIAN}

Penelitian ini memakai pendekatan kualitatif yang bersifat kasus eksploratif, guna mengeksplor penyelenggaraan pendidikan kecakapan hidup "otomotif roda dua” yang berkembang di Pondok Pesantren Darul Hikam Banjaran Kabupaten Bandung. Penelitian ini juga menggunakan model CIPP dari Stufflebeam sebagai pisau analisanya. ${ }^{22}$ Model CIPP (Context, Input, Process, Product) adalah suatu model yang menggunakan pendekatan yang berorientasi kepada pemegang keputusan guna membantu dalam pembuatan keputusan.

Pengumpulan data dalam penelitian ini menggunakan teknik observasi, studi dokumentasi dan wawancara dengan informan pengurus pondok, ustadz dan santri yang mengikuti program kecakapan hidup, alumni serta masyarakat sekitar pondok.

Teknik analisis yang digunakan mencakup tiga proses analisis seperti yang dikemukakan oleh Miles dan Huberman ${ }^{23}$ yaitu:1). Reduksi data, yakni setelah data terkumpul melalui wawancara dan studi dokumentasi serta observasi, direduksi sedemikian rupa sehingga tidak ada lagi data yang dianggap tidak sesuai dengan masalah dan tujuan penelitian; 2). Penyajian data dengan cara mengorganisasikan dan memaparkan data. Jika dianggap perlu, untuk data yang memiliki kompleksitas tinggi digunakan tabulasi distribusi frekuensi guna lebih mudah dibaca, dipahami dan diinterpretasikan; dan 3).

${ }^{22}$ Daniel L. Stufflebeam dan Anthony J. Shinkfield. 1985. Systematic Evaluation. USA: KluwerNijhoff Publishing, h. 169-179.

${ }^{23}$ Norman K. Denzin dan Yvonna S. Lincoln (Eds). 1994. Handbook of Qualitative Research. Thousand Oaks. California: SAGE Publications, h. 429. 
Penggambaran dan pembuktian yang melibatkan peneliti dalam interpretasi terhadap data yang disajikan sehingga dapat dipahami maksudnya, kemudian ditarik kesimpulan yang bertalian dengan tujuan penelitian.

\section{HASIL DAN PEMBAHASAN}

\section{Selayang Pandang Pondok Pesantren Darul Hikam}

Berdasarkan data dokumentasi, sebelum Pondok Pesantren Darul Hikam berdiri sekitar tahun 1925-1950 M, daerah Kiangroke Banjaran Kabupaten Bandung dan sekitarnya masih berupa hutan belukar yang penduduknya masih minus agama dan merupakan daerah persilatan yang dipenuhi oleh para pendekar. Oleh karena itu tidaklah heran bahwa orang-orang yang paling berwibawa dan disegani adalah para jawara silat di samping pemerintah dan orang-orang yang kaya. Awal Abad XX Masehi Wali Songo mulai bisa menembus daerah Kiangroke yang masih gersang oleh ajaran agama Islam, beberapa putra daerah Kiangroke berangkat untuk bertafaqquh fiddin (memahami dan mendalami ilmu ajaran agama Islam ke berbagai Pondok Pesantren yang terkenal saat itu).

Diantara putra daerah Kiangroke itu adalah KH. Luqman Abdul Ghani dari Pondok Pesantren Sukamiskin Bandung, pada tahun 1925 beliau mulai merintis da'wah islamiyyah melalui jalur pendidikan Madrasah Takhossus Diniyyah Salafiyyah dengan penekanan penanaman aqidah islamiyyah, tulis baca al-Quran, fiqih Ibadah mahdloh (murni) dan siroh (biografi) Nabi Muhammad Saw.
Tantangan, rintangan dan hambatan medan da'wah yang dihadapi cukup berat ditambah dengan kelangkaan para da'i dan para pendidik serta sarana dan prasarana pendidikan yang masih jauh dari memadai, maka pengkaderan pun terus berlangsung. Diantara putra daerah Kiangroke lainnya adalah $\mathrm{KH}$. Ahmad Jumhur yang diberangkatkan ke berbagai Pondok Pesantren, seperti Pondok Pesantren Sukamiskin dibawah asuhan Syekh KH.Ahmad Dimyathi, Pondok Pesantren Tebu Ireng Jombang dibawah asuhan Syekh KH. Hasyim Asyari (Pendiri Nahdlatul Ulama), Pondok Pesantren Gunung Puyuh Sukabumi dibawah asuhan Syekh KH. Sanusi, Pondok Pesantren Cintawana Tasikmalaya, dan yang lainnya.

Sekembalinya KH. Ahmad Jumhur dari berbagai Pondok Pesantren bersama KH. Aqib Afifuddin dan KH. Luqman Abdul Ghani, bersama-sama mulai mendirikan suatu Lembaga Pendidikan Islam yang pada saat itu dinamakan Pesantren Islam Kiangroke dengan mulai diterapkan sistem pendidikan klasikal yang intensif yaitu mulai dari jenjang pendidikan Madrasah Ibtidaiyyah 6 tahun.

Karena mendapat sambutan yang baik dari masyarakat maka mulailah berdatangan santri - santri dari daerah lain, hal ini menuntut adanya tempat pemondokan, penambahan waktu belajar dan peningkatan mutu pendidikan yaitu dengan mempelajari kitab kuning yang merupakan sumber kajian dan rujukan ilmu ajaran Islam yang berbahasa Arab fusha.

Pada tanggal 17 Agustus 1960 atas dukungan dan peran serta Prof. Dr.KH. 
Ahmad Sanusi, yaitu salah seorang alumni PP Darul Hikam yang pada saat itu menjadi Rektor IKIP Bandung, Bupati Bandung Junaedi Warkajaya dan Kepala Kanwil Departemen Agama Propinsi Jawa Barat maka didirikanlah jenjang pendidikan tingkatan lanjutan pertama yang dinamakan Madrasah Tsanawiyah 4 tahun, mulai dimasukan pelajaran umum untuk memenuhi kebutuhan ummat; bersamaan dengan itu pula Pesantren Islam Kiangroke dirubah namanya menjadi Pondok Pesantren Darul Hikam maksudnya Pondok Pesantren ini menjadi tempat ilmu yang bermanfaat di dunia dan di akhirat kelak.

Terwujudnya lembaga pendidikan yang unggul, melandasi imtaq dan madani, merupakan visi dari Pesantren Darul Hikam. Indikator dari visi tersebut antara lain : 1), Unggul dalam kemampuan intelektual, prestasi akademik, keterampilan skill, kewirausahaan, berakhlakul karimah dan sosial kemasyarakatan (insan madani); 2). Menghasilkan lulusan-lulusan yang mampu menguasai dasar-dasar ilmu agama langsung dari sumbernya yang otentik serta menguasai iptek; 3). Mengintegrasikan pengetahuan keagamaan dan ilmu pengetahuan umum yang mumpuni, penguasaan bahasa-bahasa dan pengetahuan umum berstandar internasional; 4).Ketaatan terhadap aturan dan tuntunan yang telah dianugrahkan oleh Allah Swt serta mengutamakan kesatuan wilayah dan menghargai kebhinekaan untuk mencapai tujuan nasional; 5). Menjunjung tinggi kepentingan nasional serta kepentingan wawasan untuk menyelenggarakan dan membina kesejahteraan, kedamaian dan budi luhur serta martabat manusia.
Visi tersebut, kemudian dijabarkan kembali dalam bentuk misi sebagai berikut : 1). Mendidik secara optimal sesuai dengan bakat dan minat melalui proses pembelajaran; 2). Menyiapkan peserta didik yang memiliki kemampuan dibidang penguasaan dasar - dasar ilmu agama (imtaq) dan pengetahuan umum (iptek); 3). Menumbuhkan semangat dalam mengembangkan kurikulum sesuai dengan perkembangan zaman dan memadukan kurikulum madrasah dengan kurikulum pesantren (memelihara nilai-nilai lama yang dipandang baik dan menggali nilainilai baru yang lebih baik); 4). Melaksanakan pembelajaran dan bimbingan secara efektif serta mengembangkan potensi akademik peserta aktivitas keagamaan dan sosial kemasyarakatan (madani) yang dijiwai ajaran Islam dan memiliki ruh juang ulama; 5). Mewujudkan kader - kader pengembang, penyebar dan pengamal ajaran Islam, serta turut mencerdaskan kehidupan bangsa dan bertanggung jawab atas ketinggian tanah air, bangsa dan Negara.

\section{Pendidikan Kecakapan Hidup Otomotif Roda Dua}

\section{Context Program}

Diantara tri pusat pendidikan, lembaga pondok pesantren merupakan lingkungan kedua setelah keluarga yang cukup berperan di dalam mewarnai perilaku peserta didik. Pondok Pesantren Darul Hikam Banjaran menjadi lembaga pendidikan yang mampu menjamah aspek pembudayaan spiritual, penguasaan pengetahuan dan pemilikan keterampilan peserta didik, sehingga lulusannya memiliki jati diri secara utuh. 
Dalam kehidupan modern seperti sekarang, pondok pesantren merupakan salah satu lembaga pendidikan alternatif terbaik, karena tuntutan-tuntutan yang diperlukan bagi perkembangan anak tidak memungkinkan didapat hanya dirumah. Materi yang diberikan dipondok pesantren berhubungan langsung dengan perkembangan pribadi anak, berisikan nilai, moral dan agama, berhubungan langsung dengan pengembangan sains dan teknologi, serta pengembangan kecakapan-kecakapan tertentu yang langsung dapat dirasakan dalam pengisian tenaga kerja. ${ }^{24}$

Dengan demikian pondok pesantren tidak hanya berperan sebatas pewarisan dan pelestarian ilmu-ilmu agama, akan tetapi juga sebagai lokomotif pembaharuan masyarakat atau agen pembaharuan, karena pondok pesantren merupakan lembaga pembinaan manusia yang akan mengisi masa depan masyarakat, bangsa dan negara. Oleh karena itu, Pesantren Darul Hikam tidak berhenti pada penyampaian materi kurikulum saja, tetapi pada pengembangan dan reproduksi budaya mandiri serta penggalian potensi lokal yang disesuaikan minat dan bakat untuk membekali kecakapan para santri.

Hal tersebut, sejalan dengan program pemerintah dalam rangka memberdayakan lembaga pendidikan pedesaan dalam spektrum yang lebih luas sebagai media mempersiapkan peserta didik sebagai wira usaha dengan bekal keterampilan. Program itu juga dapat meningkatkan citra lembaga pendidikan keagamaan yang berdomisili dipedesaan disamping belajar ilmu

${ }^{24}$ U. Sadulloh. 2004. Pengantar Pilsafat Pendidikan. Bandung: Alfabeta, h. 64. kepesantrenan dan pengetahuan umum diharapkan sebagai basis penumbuhan wira usaha baru.

Dalam rangka mengimplementasikan program pemerintah tersebut, Pesantren Darul Hikam memilih salah satu tawaran dari pemerintah, dengan memberikan program Keterampilan Otomotif Roda Dua serta inter disipliner dalam pelatihan usaha, juga mengadakan pelatihan pembinaan yang terkait dengan bidang kewirausahaan. Program itu diperkuat dengan petuah pimpinan pondok yang diabadikan dalam sebuah motto "Santri Harus Hidup Pada Zamannya". Hal itu dikemukakan oleh Drs. KH. Dadang Zaim selaku perintis Pondok Pesantren Darul Hikam pada saat meresmikan Gedung Keterampilan Otomotif pada Tanggal 02 Januari 2009. ${ }^{25}$

PesantrenDarulHikammengembangkan pendidikan keterampilan kecakapan hidup bagi para santrinya yang dimuat dalam satu muatan pembelajaran dan pengembangan diri. Untuk memperkuat keberadaan program tersebut pimpinan pesantren menyusun pengurus yang diberi kekuatan hukum sebagai legalitas program melalui Surat Keputusan [SK] Pimpinan Pondok bernomor: MA.i/s/15/06/PP.02/21/I/2012. Berikut ini susunan pengurus program keterampilan otomotif roda dua:

${ }^{25}$ Hasil Wawancara dengan Deden Faoz AlMadani, MA pada tanggal 20 Maret 2015. 
Tabel 1. Susunan Pengurus Program Keterampilan Otomotif Roda Dua

\begin{tabular}{|c|l|l|l|}
\hline No & \multicolumn{1}{|c|}{ Nama } & \multicolumn{1}{|c|}{$\begin{array}{c}\text { Jabatan } \\
\text { Struktural }\end{array}$} & \multicolumn{1}{|c|}{$\begin{array}{c}\text { Jabatan } \\
\text { Kepengurusan }\end{array}$} \\
\hline 1 & $\begin{array}{l}\text { Drs. KH. Dadang Za'im } \\
\text { Affandi, M.Si }\end{array}$ & Kepala MA & Ketua \\
\hline 2 & $\begin{array}{l}\text { Deden Faoz Al-Madani, } \\
\text { MA }\end{array}$ & Guru & Wakil Ketua \\
\hline 3 & Sofian & Staf Tata Usaha & Sekretaris \\
\hline 4 & Ade Mintarsih & Bendahara MA & Bendahara \\
\hline 5 & Imas Siti Nurrohmah, S.Ag & $\begin{array}{l}\text { Kepala Tata } \\
\text { Usaha }\end{array}$ & Anggota \\
\hline 6 & Agus Solihin, M.Ag & Guru & Anggota \\
\hline 7 & Yayat Syarif Hidayat, S.H.I & Wali Kelas XI & Anggota \\
\hline 8 & Aep Saefulloh, BA & Wali Kelas XII & Anggota \\
\hline
\end{tabular}

Sumber : Yayasan Pendidikan Darul Hikam (2015)

Jenis program yang di pilih Pesantren Darul Hikam Banjaran sangat relevan dengan potensi lokasi pesantren yang terletak di perbatasan kota yang merupakan salah satu dataran tinggi di wilayah Bandung Selatan. Posisinya berada dipinggiran jalan provinsi yang menghubungkan tiga kecamatan: Banjaran, Cimaung dan Pangalengan. Banjaran merupakan pusat perbelanjaan masyarakat Bandung Selatan, sementara Cimaung dan Pangalengan merupakan daerah yang kaya dengan objek wisata, seperti : Bumi Perkemahan Gunung Puntang, Situ Cilenca, pemandian air panas, perkebunan teh yang menghampar, bahkan tidak sedikit situs-situs bersejarah disekitar wilayah tersebut. Hal itu mengundang perhatian turis domestik bahkan mancanegara, sehingga hampir setiap hari ramai dengan kendaraan yang hendak melakukan karya wisata. Bahkan setiap ahir pekan atau musim liburan, jalanan di banjiri oleh kendaraan-kendaran mewah baik mobil ataupun sepeda motor dan tak terelahkan terjadi kemacetan ${ }^{26}$

Melihat kondisi lingkungan seperti itu, menjadikan salah satu alasan Pesantren Darul Hikam untuk mengembangkan berbagai program kecakapan hidup bagi peserta didik yang berbasis potensi lokal dan kemandirian. Namun demikian, diantara sekian banyak program kecakapan hidup yang dikembangakan di Pesantren Darul Hikam, keterampilan otomotif roda dua merupakan unggulan dan kebanggaan karena sudah memiliki pengakuan dari masyarakat, dunia usaha dan dunia industri.

Tujuan dari pengadaan program pembinaan kecakapan hidup otomotif roda dua di Pondok Pesantren Darul Hikam adalah : 1). Memberdayakan lembaga pendidikan pedesaan dalam spectrum yang lebih luas sebagai media mempersiapkan peserta didik menjadi wirausaha dengan bekal keterampilan teknis usaha dan manajemen usaha; 2). Meningkatkan citra lembaga pendidikan keagamaan di pedesaan bukan hanya sebagai tempat belajar ilmu pengetahuan saja, tapi juga sebagai basik penumbuhan wirausaha baru atau tempat mempersiapkan calon wirausaha baru; 3). Membangun model kaderisasi wirausaha baru yang sistemik, dengan prioritas pada mereka yang berasal dari kalangan grass root di pedesaan; 4). Menjadikan lembaga pendidikan pedesaan sebagai sumber pengkaderan calon wirausaha baru yang tiada habis-habisnya.

Berdasarkan hal tersebut di atas, maka sasaran program otomotif roda dua di Pesantren Darul Hikam Banjaran di

${ }^{26}$ Hasil wawancara dengan Komara, (Pengurus Pondok) tanggal 15 Maret 2015. 
prioritaskan kepada: 1). Peserta Didik / Santri Kelas X, XI dan XII MA YPP Darul Hikam; 2). Dewan Guru MD/MI/MTs/MA YPP Darul Hikam. Sedangkan targetnya adalah peningkatan kualitas keterampilan masyarakat pondok pesantren melalui peningkatan perekonomian santri dan ustadz dengan cara menjadi tenaga pendampingbagi pemberdayaan masyarakat di luar pondok, sehingga dapat menopang kehidupan pesantren.

\section{Input Penyelenggaraan}

Salah satu keistimewaan pendidikan sistem pondok pesantren adalah sistem boarding school atau system asrama. ${ }^{27}$ Dengan sistem ini, para santri sepanjang hari dari siang sampai malam berada dalam lingkungan belajar. Mereka bergaul bersama santri yang lain dan para ustadz serta kyai mereka. Para kyai atau ustadz memantau dan mengarahkan setiap perilaku santri sepanjang hari. Selain itu, dengan bergaul sepanjang waktu, memungkinkan bagi santri untuk mencontoh perilaku dan cara hidup kyai.

Jumlah santri secara keseluruhan di Pesantren Darul Hikam pada tahun pelajaran 2014-2015 sebanyak 860 santri yang terdiri dari 429 santri putra dan 431 santri putri, namun dari sekian banyak jumlah santri tersebut baru sebagian kecil yang bisa mengikuti program keterampilan otomotif. Hal ini disebabkan karena keterbatasan sarana kelas dan tempat praktek. Sehingga untuk sementara baru bisa diikuti oleh 202 santri yang duduk tingkat Aliyah yang

${ }^{27}$ Suharno. Harian Pikiran Rakyat. Edisi Jum`at, 17 Juli 2009. terdiri dari 99 santriwan dan 103 santriwati. Berikut data santri secara keseluruhan:

Tabel 2. Data Santri Pesantren Darul Hikam

\begin{tabular}{|c|l|c|c|c|}
\hline \multirow{2}{*}{ No } & \multirow{2}{*}{ Nama } & \multicolumn{2}{|c|}{ Jumlah } & \multirow{2}{*}{ Total } \\
\cline { 3 - 4 } & & Santriwan & Santriwati & \\
\hline 1 & Madrasah Diniyah & 135 & 109 & 244 \\
\hline 2 & Madrasah Ibtidaiyah & 71 & 73 & 144 \\
\hline 3 & Madrasah Tsanawiyah & 124 & 146 & 270 \\
\hline 4 & Madrasah Aliyah & 99 & 103 & 202 \\
\hline & & 429 & 431 & 860 \\
\hline
\end{tabular}

Sumber : Yayasan Pendidikan Darul Hikam (2015)

Dari sekian banyak santri, hanya sebagian kecil santri yang tinggal di asrama, terutama santri tingkat MTs dan MA. Dalam kehidupan asrama, para santri mendapatkan pembelajaran dan pengalaman hidup. Kyai dan para ustadz hidup berdampingan dengan para santri di lingkungan pondok pesantren untuk sebanyak-banyaknya memberikan pengaruh yang baik. Pola pendidikan sistem pesantren (boarding school) ini sangat baik untuk pembentukan karakter santri sebagai peserta didik.

Para santrisebagai pembelajar mengikuti kegiatan pendidikan keagamaan dari pagi hingga sore dan malam hari. Selama 24 jam, para santri berada di bawah bimbingan dan pengawasan kyai. Di bangku madrasah, para santri dipacu untuk menguasai ilmuilmu agama secara intensif. Sementara diasrama, santri diterpa untuk menerapkan ajaran agama dan mengekspresikannya serta mematangkan berbagai jenis kecakapan yang didapatkan di bangku madrasah dalam kehidupan sehari-hari.

Hari-hari santri adalah hari-hari berinteraksi dengan teman sebaya dan kyai atauparaustadz.Darisegisosial,santribelajar bermasyarakat dalam lingkungan yang heterogen. Sedangkan dari segi semangat 
agama, pondok pesantren menjadikan pendidikan yang seimbang antar kebutuhan jasmani dan ruhani, intelektual, emosional dan spiritual serta pengembangan kemandirian dan keterampilan. Berikut jadwal kegiatan sehari-hari santri asrama:

Tabel 3. Jadwal Kegiatan Harian Santri

\begin{tabular}{|c|c|l|}
\hline No & Waktu & \multicolumn{1}{|c|}{ Kegiatan } \\
\hline 1 & $03.00-03.15$ & $\begin{array}{l}\text { Bangun tidur dan persiapan } \\
\text { Qiyamullail }\end{array}$ \\
\hline 2 & $03.15-04.15$ & Qiyamullail berjama'ah \\
\hline 3 & $04.15-04.20$ & Persiapan Sholat Subuh \\
\hline 4 & $04.20-04.30$ & Sholawatan \\
\hline 5 & $04.30-05.30$ & Sholat Subuh Berjama'ah dan Awrod \\
\hline 6 & $05.30-06.30$ & Pengajian Pesantren (Salafi) \\
\hline 7 & $06.30-07.30$ & Istirahat dan Persiapan \\
\hline 8 & $07.30-11.50$ & Kegiatan Madrasi \\
\hline 9 & $11.50-12.00$ & Persiapan Sholat Dzuhur Berjama'ah \\
\hline 10 & $12.00-12.30$ & Sholat Dzuhur Berjama'ah \\
\hline 11 & $12.30-13.00$ & Tadarus/ Muhadloroh \\
\hline 12 & $13.00-14.30$ & Istirahat \\
\hline 13 & $14.30-15.15$ & Persiapan Sholat Ashar Berjama'ah \\
\hline 14 & $15.15-15.45$ & Sholat Ashar berjama'ah \\
\hline 15 & $15.45-16.00$ & Persiapan \\
\hline 16 & $16.00-17.30$ & Pengembangan Diri Keterampilan \\
\hline 17 & $17.30-18.00$ & Istirahat dan Persiapan Sholat \\
\hline 18 & $18.00-18.30$ & Shoghrib Berjama'ah Maghrib Berjama'ah \\
\hline 19 & $18.30-19.00$ & Tadarus \\
\hline 20 & $19.00-19.30$ & Shalat Isya berjama'ah \\
\hline 21 & $19.30-21.00$ & Pengajian Salafi \\
\hline 22 & $21.00-21.30$ & $\begin{array}{l}\text { Pengabsenan dan Penutupan Gerbang } \\
\text { Utama }\end{array}$ \\
\hline 23 & $21.30-03.00$ & Istirahat (Tidur Malam) \\
\hline
\end{tabular}

Sumber : Wakamad Bidang Asrama (2015)

Dalam rangka menunjang program pesantren yang begitu banyak, Pesantren Darul Hikam Banjaran memiliki 61 tenaga pendidik dan tenaga kependidikan, yang terdiri dari 36 laki-laki dan 25 perempuan. Dari 61 tenaga pendidik dan kependidikan, hanya 4 orang yang berstatus Pegawai Negeri Sipil (PNS), 25 orang Guru Tetap
Yayasan (GTY) dan sisanya Guru Tidak Tetap (GTT). Untuk pendidikan kecakapan hidup otomotif roda dua dipegang oleh dua orang guru dan dibantu oleh beberapa santri senior. Sementara untuk pengembangannya dilaksanakan di sore hari yang perupakan program asrama dibawah pengawasan pengasuh pondok.

Implementasi pembelajaran di Pesantren Daru Hikam Banjaran mengacu pada kurikulum Kementerian Agama yang dimodifikasi menjadi kurikulum khas Pesantren Darul Hikam. Untuk program kecakapan roda dua diberi porsi 2 jam/minggu dalam pembelajaran intra dan prakteknya dilaksanakan dalam pembelajaran pengembangan diri setelah pulang dari madrasah.

Jam pembelajaran untuk setiap mata pelajaran dialokasikan sebagaimana tertera dalam struktur kurikulum, dengan alokasi waktu satu jam pembelajaran adalah 45 menit. Untuk mata pelajaran otomotif, seorang peserta didik bisa disebut lulus apabila telah mampu mencapai standar kompetensi berikut :1). Memilih dan mengklasifikasikan peralatan servis bengkel otomotif berdasarkan fungsi dan penggunaan; 2). Menggunakan secara aman peralatan bengkel dan perlengkapan tempat kerja berdasarkan SOP (Standard Operation Prosedur), peraturan K3 (Keselamatan, Kesehatan dan Kerja); 3). Membongkarpasang/servis mesin kendaraan yang bermasalah; 4). Memelihara peralatan bengkel dan perlengkapan tempat kerja. Berikut ini salah satu contoh struktur kurikulum untuk Madrasah Aliyah: 
Tabel 4. Struktur Kurikulum Kurikulum MA Kelas XI

\begin{tabular}{|l|c|c|}
\hline \multirow{2}{*}{\multicolumn{1}{c|}{$\begin{array}{c}\text { Komponen } \\
\text { Mata Pelajaran }\end{array}$}} & \multicolumn{2}{c|}{ Alokasi Waktu } \\
\cline { 2 - 3 } & \multicolumn{2}{c|}{ Kelas XI } \\
\cline { 2 - 3 } & Smt 1 & Smt 2 \\
\hline Al- Qur'an Hadits & 2 & 2 \\
\hline Aqidah Akhlaq & 2 & 2 \\
\hline Fiqih & 2 & 2 \\
\hline Sejarah Kebudayaan Islam & & \\
\hline Pendidikan Kewarganegaraan & 2 & 2 \\
\hline Bahasa Indonesia & 4 & 4 \\
\hline Bahasa Inggris & 4 & 4 \\
\hline Matematika & 4 & 4 \\
\hline Sejarah & 3 & 3 \\
\hline Geografi & 3 & 3 \\
\hline Ekonomi & 4 & 4 \\
\hline Sosiologi & 3 & 3 \\
\hline Seni Budaya & 2 & 2 \\
\hline Pendidikan Jasmani, Olahraga dan Kesehatan & 2 & 2 \\
\hline Teknologi Informasi dan Komunikasi & 2 & 2 \\
\hline Keterampilan Otomotif Roda Dua & 2 & 2 \\
\hline Muatan Lokal & 2 & 2 \\
\hline Bahasa Sunda & 2 & 2 \\
\hline IImu Hadits & 2 & 2 \\
\hline Pengembangan Diri & 2 & 2 \\
\hline
\end{tabular}

Sumber : Wakasek Kurikulum (2015)

Kegiatan praktek otomotif roda dua di Pesantren Darul Hikam Banjaran di dukung sarana dan prasarana seperti laboratorium otomotif yang baik dan cukup memadai, namun pemeliharaan dan perawatan peralatan masik kurang terperhatikan karena sumber daya manusia yang ada belum memadai. Hal itu bila dibiarkan bisa mengakibatkan peralatan yang dimiliki akan cepat rusak, sehingga perlu segera di antisipasi.

\section{Proses Pembelajaran}

Kegiatan belajar mengajar yang digunakan oleh para kyai dan ustadz dalam penyelenggaraan pendidikan otomotif roda dua di Pondok Pesantren Darul Hikam Banjaran pada umumnya adalah latihan dan praktek, dengan komposisi 20\% teori dan $80 \%$ praktek. Selain itu, ada kerjasama dengan UPTD Balai Latihan Kerja (BLK) Kabupaten Bandung untuk kegiatan latihan, namun hal itu sering terkendala tatkala ada program khusus atau yang sulit diselesaikan pondok.

Beberapa metode yang digunakan dalam proses pembekalan kecakapan hidup otomotif roda dua di Pondok Pesantren Darul Hikam Banjaran antara lain: 1). Ceramah, digunakan ketika memulai suatu pokok bahasan; 2). Demonstrasi, yaitu melakukan peragaan suatu proses, unjuk kerja keterampilan tertentu atau suatu penampilan dihadapan para ustadz dan kyai; 3) Diskusi, diterapkan sebagai diskusi kelas untuk menghasilkan interaksi antara santri dengan santri atau antara santri dengan ustadz atau kyai dalam hal menganalisis permasalahan yang ditemukan pada saat unjuk kerja; 4). Tutorial, yaitu pemberian kesempatan kepada santri untuk berkonsultasi pada ustadz atau kyai secara mandiri; dan 6) Praktikum, yaitu kegiatan untuk melakukan pengamatan, percobaan, pengumpulan data yang dilakukan di laboratorium atau tempat lain yang disamakan dengan laboratorium dan workshop, melakukan pembahasan dan pelaporan.

Proses pembelajaran otomotif roda dua dilakukan di gedung keterampilan yang tersedia. Dalam proses pembelajaran keterampilan yang menjadi fokus utama adalah kegiatan belajar santri. Peran ustadz adalah hanya sebagai fasilitator belajar santri, sehingga penekanannya adalah bagaimana santri belajar. Disamping itu, 
ustadz memberi contoh cara kerja yang benar dan mengawasi kegiatan individual santri. Media dan bahan ajar yang digunakan mencakup: bahan yang diperoleh melalui internet berupa modul, jobshet dan peralatan praktek.

Untuk membantu pencapaian tujuan program pendidikan otomotif roda dua pada Pondok Pesantren Darul Hikam, maka diadakan praktek kerja lapangan yang diarahkan agar santri dapat: 1) Memperdalam dan memperluas penguasaan keterampilan;2). Menghayati suasana (iklim) kerja dalam situasi yang sesungguhnya; 3). Menginternalisasi etos kerja secara positif.

Pengelolaan pendidikan otomotif roda dua secara teknis operasional kewenangannya ada pada masing-masing ustadz bidang keterampilan, sementara kebijakan pembiayaan sepenuhnya kewenangan berada di tangan kyai sebagai pimpinan pondok. Sumber pembiayaan yang menunjang program pengembangan otomotif roda dua meliputi pemanfaatan potensi yang ada dari masyarakat pondok pesantren dan sumbangan dana dari pemerintah. Berikut contoh biaya operasional yang diperlukan untuk biaya praktek persemester:

Tabel 6. Biaya Peralatan Praktek Praktek

\begin{tabular}{|c|l|c|r|r|}
\hline No & Nama Barang & Volume & \multicolumn{1}{|c|}{$\begin{array}{c}\text { Harga } \\
(\text { Rp })\end{array}$} & Besar (Rp) \\
\hline \multicolumn{5}{|c|}{ Peralatan Praktek Keterampilan Otomotif Roda Dua } \\
\hline 01 & Complessor & 1 & $4.500 .000,-$ & $4.500 .000,-$ \\
\hline 02 & Back Lift & 2 & $4.500 .000,-$ & $9.000 .000,-$ \\
\hline 03 & Gerinda Duduk & 1 & $800.000,-$ & $800.000,-$ \\
\hline 04 & Las Listrik & 1 & $1.000 .000,-$ & $1.000 .000,-$ \\
\hline 05 & Tool Kit & 1 set & $6.000 .000,-$ & $6.000 .000,-$ \\
\hline 06 & Etalase & 1 set & $3.000 .000,-$ & $3.000 .000,-$ \\
\hline 07 & $\begin{array}{l}\text { Pemadam } \\
\text { Kebakaran }\end{array}$ & 1 & $1.000 .000,--$ & $1.000 .000,-$ \\
\hline
\end{tabular}

\begin{tabular}{|c|l|c|c|r|}
\hline 08 & Mesin Motorv & 3 & $5000.000,-$ & $15.000 .000,-$ \\
\hline 09 & Steem & 1 set & $2.000 .000,-$ & $2.000 .000,-$ \\
\hline 10 & Catok & 1 & $1.000 .000,-$ & $1.000 .000,-$ \\
\hline
\end{tabular}

Sumber : Kepala Laboratorium Otomotif (2015)

\section{Produk Kegiatan}

Pergeseran industri otomotif di Indonesia saat ini penting bagi kemajuan bangsa yang membutuhkan mobilitas yang tinggi, sehingga ini merupakan wadah positif bagi pelaku industri otomotif maupun konsumen yang ingin mengetahui perkembangan terkini.

Pendidikan kecakapan hidup bidang otomotif roda dua yang dikembangkan Pesantren Darul Hikam telah berhasil mendidik santri dalam hal wawasan tentang dunia otomotif roda dua, juga beberapa santri telah mampu mengembangkan keterampilan dengan menciptakan lapangan kerja, bahkan tidak sedikit santri yang sudah siap memasuki dunia kerjadi bidang otomotif sehingga dapat berinovasi untuk hidup mandiri. ${ }^{28}$ Kecakapan hidup bidang otomotif yang dikembangkan Pesantren Darul Hikam ternyata tidak hanya membuka lapangan kerja baru tetapi juga mendukung perkembangan Usaha Kecil Menengah (UKM). Salah satu UKM yang merasakan manfaat program ini adalah masyarakat sekitar pondok yang bergerak di bidang produksi berbagai perlengkapan otomotif.

\section{PENUTUP}

Dari hasil keseluruhan pembahasan dan mengacu pada permasalahan yang diangkat

${ }^{28}$ Hasil Wawancara dengan Ucu Saefurrohman, (Alumni Pesantren Darul Hikam Tahun 2010) pada tanggal 25 Maret 2015 
pada penelitian ini, maka bisa diambil kesimpulan sebagai berikut: Pertama, sebagai salah satu upaya pemberdayaan potensi lokal dan media mempersiapkan santri untuk menjadi wirausaha Pesantren Darul Hikam Banjaran berupaya meningkatkan kualitas santri dengan memberikan pendidikan kecakapan hidup otomotif roda dua melalui legalitas program Surat Keputusan Pimpinan Pondok Nomor:MA.i/s/15/06/ PP.02/21/I/2012.

Kedua, Pesantren Darul Hikam Banjaran mengembangkan berbagai program kecakapan hidup bagi peserta didik yang berbasis potensi lokal dan kemandirian. Namun diantara sekian banyak program kecakapan hidup yang dikembangakan, Darul Hikam, keterampilan otomotif roda dua merupakan unggulan dan kebanggaan karena banyak siswa sudah memiliki pengakuan dari masyarakat, dunia usaha dan dunia industri.

Ketiga, Pelaksanaan pembelajaran otomotif roda dua di Pondok Pesantren Darul Hikam Banjaran terintegrasi dalam program madrasi untuk pembekalan teori, sementara untuk pendalamannya masuk pada program pengembangan diri yang disediakan di sore hari yang include dengan program asrama dengan dengan komposisi 20\% teori dan 80\% praktek. Keempat, Pendidikan kecakapan hidup yang dikembangkan Pesantren Darul Hikam Banjaran telah berhasil membekali mempunyai wawasan tentang dunia otomotif roda dua dan siap memasuki dunia kerja.

Bertolak dari kesimpulan di atas, maka dapat dikemukakan beberapa saran sebagai berikut: Pertama, Program pendidikan kecakapan hidup yang dikembangkan
Pesantren Darul Hikam perlu mendapat apresiasi dari pemegang kebijakan. Oleh karena itu perlu dilakukan koordinasi antara Pesantren Darul Hikam Banjaran dengan pemerintah Kabupaten Bandung dan Kementerian Agama (khususnya Direktorat Pendidikan Keagamaan dan Pondok Pesantren) dalam rangka memberikan pelayanan kurikulum, pengembangan sarana dan prasarana serta pelatihan bagi tenaga pendidiknya.

Kedua, Pendidikan kecakapan hidup otomotif roda dua lebih efektif menggunakan strategi pembelajarannya berbasis kerja yaitu pendekatan pembelajaran yang menggunakan konteks tempat kerja disamping menyeimbangkan antara pembekalan teori dan praktik secara proporsional. Untuk itu Pesantren Darul Hikam perlu membuka hubungan kerja secara inten dengan industri otomotif setempat atau Balai Latihan Kerja (BLK).

\section{UCAPAN TERIMA KASIH}

Penelitian ini dapat terealisasi dengan baik karena mendapatkan dukungan dari banyak pihak. Oleh karena itu, kami sampaikan ucapan terimakasih atas kerjasama dan dukungannya, terutama kepada asisten peneliti Bapak Komara Santika IES yang telah membantu melakukan pengumpulan data dengan baik. Terima kasih juga disampaikan kepada segenap pimpinan Pondok Pesantren Darul Hikam Banjaran yang telah memberi kemudahan dalam mengakses berbagai data dilapangan, juga kepada Kepala Balai Penelitian dan Pengembangan Agama Jakarta yang telah memberikan support moril dan materil terhadap penyelenggaraan penelitian ini. 
Selain itu, dihaturkan terima kasih kepada semua pihak yang telah memberikan masukan, saran dan membantu secara teknis dalam penyempurnaan tulisan hasil ini. Tak lupa penulis haturkan terima kasih kepada redaktur Jurnal Edukasi yang bersedia menerbitkan tulisan ini.

\section{DAFTAR PUSTAKA}

Abdullah, Taufik (1987): Islam dan Masyarakat: Pantulan Sejarah Indonesia. Cetakan I. Jakarta, LP3ES.

A'la, Abd (2006): Pembaruan Pesantren. Cetakan I. Yogyakarta, Pustaka Pesantren.

Arifin, Imron (1993): Kepemimpinan kyai, kasus: Pesantren tebuireng. Malang, Kalimasahada Press.

Azra, Azyumardi (2000): Pendidikan Islam, Tradisi dan Modernisasi Menuju Millenium Baru. Jakarta, Logos.

Daulay, Haidar Putra (2007): Sejarah Pertumbuhan dan Pembaruan Pendidikan Islam di Indonesia. Jakarta, Kencana.

Dawam, Ainurrafiq dan Ahmad Ta'arifin (2005): Manajemen Madrasah Berbasis Pesantren. Yogyakarta, Listafariska Putra.

Denzin, Norman K. dan Yvonna S. Lincoln (Eds) (1994): Handbook of Qualitative Research. Thousand Oaks. California, SAGE Publications.

Departemen Agama (2005): Pedoman Integrasi Life skill dalam pembelajaran. Jakarta, Direktorat Jederal Kelembagaan Agama Islam.

Departemen Pendidikan Nasional (2010): Model Integrasi Pendidikan Kecakapan
Hidup. Jakarta, Pusat Kurikulum Badan Penelitian dan Pengembangan.

Djamaluddin \& Abdullah Aly (1998): Kapita Selekta Pendidikan Islam. Bandung, Pustaka Setia.

Dhofier, Zamakhsyari (1990): Tradisi Pesantren: Studi tentang Pandangan Hidup Kyai. Jakarta, LP3ES.

Dudin, Achamad (2013): "Pengembangan Ekonomi Pada Lima Pesantren Kabupaten Lamongan, Jawa Timur." Edukasi Jurnal Pendidikan Agama dan Keagamaan, 11 (1): 113-128.

Jailani, HA. Timur (1983): Peningkatan Mutu Pendidikan Islam dan Pengembangan Perguruan Agama. Jakarta, Darmaga.

Khozim, Wahid (2011): “Perberdayaan Ekonomi Pesantren: Studi Kasus Pesantren Nurul Mursyidah Pandeglang." Edukasi Jurnal Pendidikan Agama dan Keagamaan, 9 (1): 4252-4273.

M,Abd Kadir (2015): "Pemberdayaan Santridi Pondok Pesantren Attarbiyatussakilah Kota Kendari." Al-Qalam Jurnal Penelitian Agama dan Sosial Budaya, 21 (2): 221233.

Malik, Abdul (2008): Inovasi Kurikulum Berbasis Lokal di Pondok Pesantren. Jakarta, Balitbang.

Masyuri, Aziz (2002): Implementasi Akhlak Qur'ani. Makalah disampaikan pada Kontribusi Pesantren Terhadap Perubahan Sosial Budaya Masyarakat Indonesia. PT Telekomunikasi Indonesia Tbk. Bandung, 23 April.

Partanto, Pius dan M. Dahlan al Barry (1994): Kamus Ilmiah Populer. Surabaya, Arkola.

RPJP dan Renstra Pendidikan Islam Kementerian Agama 2014 - 2019.

Sadulloh, U (2004): Pengantar Pilsafat Pendidikan. Bandung, Alfabeta. 
Steenbrink, Karel A (1974): Pesantren, Madrasah, Sekolah. Jakarta, LP3ES.

Stufflebeam, Daniel L. dan Anthony J. Shinkfield (1985): Systematic Evaluation. USA, Kluwer-Nijhoff Publishing.

Suharso (2009): Harian Pikiran Rakyat. Edisi Jum`at, 17 Juli.
Tim Broad Based Education Depdiknas (2002): Kecakapan Hidup life Skill Melalui Pendekatan Pendidikan Berbasis Luas. Surabaya, SIC.

Undang-Undang Republik Indonesia No.20 Tahun 2003 Tentang Sistem Pendidikan Nasional. 